УДК 911.3:33

https://doi.org/10.52058/2708-7530-2021-9(15)-133-141

Кузьмичук Олександр Валерійович аспірант кафедри управління та бізнес-адміністрування, Інститут післядипломної освіти та довузівської підготовки, ДВНЗ «Прикарпатський національний університет імені Василя Стефаника», вул. Шевченка, 57, м. Івано-Франківськ, 76018, тел.: (034) 278-81-05, e-mail: oleksandr.kuzmychuk@ pnu.edu.ua, https://orcid.org/0000-0001-7004-6416

Польова Леся Василівна кандидат педагогічних наук, доцент кафедри готельно-ресторанної та курортної справи, Факультет туризму, ДВНЗ «Прикарпатський національний університет імені Василя Стефаника», вул. Шевченка, 57, м. Івано-Франківськ, 76018, тел.: (034)2788105, e-mail: polyovy@ukr.net, https://orcid.org/0000-0003-2971-5993

Шикеринець Василь Васильович кандидат наук з державного управління, доцент, завідувач кафедри управління соціокультурною діяльністю, шоу-бізнесу та івентменеджменту, заступник декана факультету туризму з наукової роботи, ДВНЗ «Прикарпатський національний університет імені Василя Стефаника», вул. Шевченка, 57, м. Івано-Франківськ, 76018, тел.: (095) 4239468, e-mail: vasyl.shykerynets@pnu.edu.ua, https://orcid.org/0000-0002-6845-1639

\title{
РЕАЛІЗАЦІЯ ДЕРЖАВНОЇ ПОЛІТИКИ В САНАТОРНО-КУРОРТНИХ КОМПЛЕКСАХ (НА ПРИКЛАДІ ІВАНО-ФРАНКІВСЬКОЇ ОБЛАСТІ)
}

Анотація. Курортна діяльність займає значне місце в зміцненні здоров'я населення нашої країни. Однією з найважливіших проблем державної соціальноекономічної політики є забезпечення умов для фізичного та психоемоційного відновлення працівників. Необхідно стимулювати розвиток рекреаційної системи України. Разом з тим існує ряд проблем, що перешкоджають цьому. Управління санаторно-курортної діяльністю має історичні традиції і $є$ справою складною, але перспективною.

Державна політики розвитку курортної справи в Україні, має комплекс лікувально-профілактичних заходів, спрямованих на зміцнення здоров'я людини, серед яких особливе місце займає санаторно-курортне лікування та оздоровлення. Особливу значущість даний напрямок набуває в зв'язку з переходом вітчизняної охорони здоров'я від системи, орієнтованої переважно на лікування захворювань, до системи охорони здоров'я громадян, заснованої на підвищенні функціональних можливостей організму і профілактики захворювань.

Реалізація державної санаторно-курортної політики на регіональному рівні це, з одного боку, істотна складова стратегії туристичного розвитку України, яка 
реалізується відповідно до загальних завдань державної політики; з іншого боку, ця політика виступає як самостійна сфера проектної діяльності, що має на меті всебічну підтримку та популяризацію санаторно-курортну індивідуальність кожного регіону, створення умов для розвитку туристичного життя даної територіальної громади.

Регіональну політику потрібно розробляти як складову державної політики, яка поєднує економічні, організаційно-правові заходи, що здійснюються державними органами влади як складову розвитку регіонів на основі підтримки природнього ресурсу, людського, виробничого та при врахуванні особливостей кожної регіональної одиниці у відповідності до державних інтересів. При реалізації регіональної політики держава впливає на стратегію та процеси в регіонах.

Ключові слова: державна політика, санаторно-курортні послуги, система управління, державна влада, рекреація.

Kuzmychuk Oleksandyr Valeriiovych Postgraduate student of the Department of Management and Business Administration, Institute of Postgraduate Education and Pre-University Training, Vasyl Stefanyk Precarpathian National University, Shevchenka St., 57, Ivano-Frankivsk, 76018, tel.: (034) 2788105, e-mail: oleksandr.kuzmychuk@pnu.edu.ua, https://orcid.org/0000-0001-7004-6416

Polova Lesya Vasylivna PhD Candidate of pedagogical sciences, Associate Professor of the Department of Hotel-Restaurant and Resort Business, Faculty of Tourism, Vasyl Stefanyk Precarpathian National University, Shevchenko St.,57, Ivano-Frankivsk, 76018, tel.: (034)2788105, e-mail: polyovy@ukr.net, https://orcid.org/0000-0003-2971-5993

Shykerynets Vasyl Vasilyevich Phd in public administration, Associate Professor, Head of the Department of Sociocultural Activities Management, Show Business and Event Management, associate dean Faculty of Tourism, Vasyl Stefanyk Precarpathian National University, Shevchenko St., 57, Ivano-Frankivsk, 76018, tel.: (095) 423-94-68, e-mai: vasyl.shykerynets@ @nu.edu.ua, https://orcid.org/0000-0002-6845-1639

\section{IMPLEMENTATION OF STATE POLICY IN SANATOR AND RESORT COMPLEXES (ON THE EXAMPLE OF IVANO-FRANKIVSK REGION)}

Abstract. Resort activities play a significant role in strengthening the health of the population and our country. One of the most important problems of state socio-economic policy is to provide conditions for physical and psycho-emotional recovery of employees. It is necessary to stimulate the development of the recreational system of Ukraine. However, there are a number of problems that prevent this. Management of sanatorium-resort activity has historical traditions and is a difficult but promising business. 
The state policy of resort business development in Ukraine has a set of treatment and prevention measures aimed at strengthening human health, among which a special place is occupied by sanatorium treatment and rehabilitation. This area is especially important in connection with the transition of domestic health care from a system focused mainly on the treatment of diseases, to a public health system based on improving the functional capabilities of the body and disease prevention.

The implementation of the state sanatorium and resort policy at the regional level is, on the one hand, an essential component of the tourism development strategy of Ukraine, which is implemented in accordance with the general objectives of state policy; on the other hand, this policy acts as an independent sphere of project activity, which aims to comprehensively support and promote the sanatorium-resort individuality of each region, creating conditions for the development of tourist life of the territorial community.

Regional policy should be developed as a component of public policy that combines economic, organizational and legal measures taken by public authorities as part of regional development based on support of natural resources, human, production and taking into account the characteristics of each regional unit in accordance with state interests. In implementing regional policy, the state influences the strategy and processes in the regions.

Keywords: state policy, sanatorium services, management system, state authority, recreation.

Постановка проблеми. В даний час головним фактором економічного розвитку стає людський капітал. У зв'язку з цим особливу увагу привертає сфера, яка в значній мірі забезпечує відтворення людського капіталу, - туристична галузь. Туристську індустрію можна охарактеризувати, як сукупність готелів і інших засобів розміщення, засобів транспорту, об'єктів громадського харчування, об'єктів і засобів розваги. Масштаби туризму за останні кілька десятиліть зростають вражаючими темпами, збільшується частка продукції рекреаційного сектора у валовому світовому продукті.

У розвинених індустріальних країнах усвідомлюють важливість підтримки відновлення трудових ресурсів. Наприклад, в Німеччині існує велика i різноманітна практика оплати частини лікувально - оздоровчого відпочинку на курортах за державний кошт. У багатьох країнах діють програми податкових пільг для санаторіїв і бальнеологічних об'єктів.

Санаторно-курортна діяльність займає значне місце в зміцненні здоров'я населення i нашої країни. Однією 3 найважливіших проблем державної соціально-економічної політики $є$ забезпечення умов для фізичного та психоемоційного відновлення працівників. Необхідно стимулювати розвиток рекреаційної системи України. Разом 3 тим існує ряд проблем, що перешкоджають цьому. Управління санаторно-курортної діяльністю має досить тривалі історичні традиції і $є$ справою складною, але вельми перспективною. 
Санаторно-курортна діяльність, регламентується не тільки державна політика, а значною мірою, міжнародними юридичними нормами, що визначають основні засади розвитку та якості надання послуг, також значна увага надана користувачам послуг і можливості безперешкодно їх отримувати у різних країнах світу. Існують міжнародні нормативно-правові акти, згідно яких

відбувається розвиток сфери санаторно-курортних послуг в усіх країнах світу, включно з Україною.

Державна політики розвитку курортної справи в Україні, має комплекс лікувально-профілактичних заходів, спрямованих на зміцнення здоров'я людини, серед яких особливе місце займає санаторно-курортне лікування та оздоровлення. Особливу значущість даний напрямок набуває в зв'язку з переходом вітчизняної охорони здоров'я від системи, орієнтованої переважно на лікування захворювань, до системи охорони здоров'я громадян, заснованої на підвищенні функціональних можливостей організму і профілактики захворювань.

Важливе місце належить санаторно-курортної допомоги в організації медичної реабілітації осіб, які постраждали від нещасних випадків на виробництві та професійних захворювань, в реабілітації хворих безпосередньо після стаціонарного лікування 3 приводу важких захворювань i оперативних втручань на серці, судинах i шлунково-кишковому тракті. Курорти України мають у своєму розпорядженні практично всіма відомими в світі типами лікувальних мінеральних вод, лікувальних грязей та інших природних лікувальних факторів, ресурси яких забезпечують існуючу потребу і перспективу розвитку державної політики у сфері санаторно-курортного лікування, оздоровлення та відпочинку.

Аналіз останніх досліджень і публікацій. Вітчизняна наука не багата комплексними дослідженнями у сфері санаторно-курортних послуг. Водночас низка питань функціонування та розвитку рекреаційно-туристичної сфери i використання рекреаційного потенціалу розглядалася численними вітчизняними науковцями, зокрема такими, як О. Бейлик, М. Бойко, М. Борущак, Б. Буркинський, В. Васильчак, Л. Гринів, П. Гудзь, О. Гулич, А. Єлістратова, В. Єфимова, О. Жидяк, В. Кифяк, М. Мальська, А. Пегушина, М. Пітюлич, О. Севастьянова, В. Смолій, Чайковська. Проблематика регіональної рекреаційної політики та регіонального розвитку досліджувалась у працях П. Жука, Ю. Стадницького, С. Шульц та інших учених.

Значний внесок у теоретичні й прикладні аспекти розвитку сфери санаторнокурортних закладів зробили зарубіжні дослідники: Н. Ален, І. Барчуков, Л. Бол, I. Інскіп, А. Параскевас, М. Стельцнер, Дж. Флетчер, Дж. Фосс Ніколай, М. Юн.

Гіпотеза дослідження грунтується на припущенні, що цілісне дослідження сутності та особливостей реалізації державної політики в санаторно-курортній сфері в сучасних умовах дасть змогу визначити основні напрями іiі оптимізації, засоби i механізми реалізації, адекватні тим процесам i тенденціям, що спостерігаються у житті українського суспільства. 
Мета статті: $\epsilon$ визначення і наукове обгрунтування основних напрямів державної політики у санаторно-курортній сфері на основі системного аналізу та особливостей іiі реалізації на прикладі Івано-Франківської області.

Відповідно до мети дослідження визначено завдання:

- проаналізувати нормативно-правове забезпечення реалізації державної політики в санаторно-курортній сфері в Україні;

- обгрунтувати теоретичні основи сучасної парадигми державного управління в санаторно-курортних комплексах;

- проаналізувати інституційні передумови реалізації державної політики в санаторно-курортній сфері у контексті децентралізаційних змін;

- окреслити організаційно-правовий механізм реалізації державної політики в санаторно-курортній сфері на регіональному рівні;

- розкрити соціально-економічний потенціал для здійснення ефективної реалізації державної політики в санаторно-курортній сфері у Івано-Франківській області;

- виявити можливості застосування особливостей моделей та підходів світової політики у вітчизняну практику;

Об’єкт дослідження - державна політика у санаторно-курортній сфері в Україні.

Предмет дослідження - особливості й шляхи реалізації державної політики у санаторно-курортній сфері в Івано-Франківської області.

Методи дослідження. Для вирішення поставлених завдань дослідження у роботі використано такі методи пізнання:

- аналізу і синтезу - для обгрунтування необхідності та розкриття сутності реалізації державної політики в санаторно-курортній сфері, а також для обстеження сучасної нормативно-правової бази України, що регламентує функціонування даної сфери;

- економіко-статистичного аналізу - для визначення тенденцій розвитку санаторно-курортної сфери України та вивчення іï сучасного стану на регіональному рівні;

- логічний та історичний - для аналізу розвитку понять “державна політика”, “санаторно-курортна сфера" у наукових працях 3 державного управління, історії культури, культурології, менеджменту, філософії;

- структурно-функціональний - для дослідження організаційної структури органів управління санаторно-курортною сферою.

Виклад основного матеріалу: Уривчасті відомості про лікувальні місцевостях України містяться ще в творах письменників давнини $i$ середньовіччя.

Активний розвиток курортної зон зумовило формування мережі курортних закладів. У практику курортної справи впроваджувалися нові прогресивні форми курортного лікування, підвищувався рівень комфортності, але почався в кінці 80-х рр. розвал економіки вдарив по курортній системі країни: погіршилася якість 
обслуговування, знизився рівень харчування, зросли ціни на путівки.

Залишившись без державного фінансування оздоровниці не змогли перейти на самофінансування. Комунальні витрати стали непомірно високі, що відбивались на вартості путівок. Зубожіле населення не мало можливості оплачувати відпочинок. Санаторно-курортна мережа почала «розвалюватися». Багаті люди вважали за краще відпочинок за кордоном, які відрізнялись високою комфортністю і великою різноманітністю лікувальних послуг. Рівень цих установ у багато разів перевищував рівень відомих світових лікувальних курортів.

Це призвело до того, що санаторно-курортні заклади багато в чому втратили свою соціальну значимість. Програючи в комфорті елітним курортам, їм важко стало забезпечувати заповнюваність. Багато санаторіїв стали нерентабельні і закрилися.

На сьогоднішній час головною метою державної політики в галузі туризму $є$ створення в Україні сучасного високоефективного і конкурентоспроможного санаторного-курортного комплексу, що забезпечує широкі можливості для задоволення потреб українських та іноземних громадян в різноманітних туристських послугах.

Основні завдання:

Формування сучасної маркетингової стратегії просування туристичного продукту на внутрішньому та міжнародному ринках шляхом:

Розробки та реалізації рекламно-інформаційних програм 3 в'їзного та внутрішнього туризму, в тому числі створення циклових теле- і радіопрограм для України i зарубіжних країн, а також проведення регулярних рекламноінформаційних кампаній в періодичних 3MI;

Видання каталогів, буклетів, карт та іншої рекламно-інформаційної друкованої продукції;

Організації та проведення міжнародних туристичних виставок, в тому числі створення єдиного національного стенду із залученням до участі органів виконавчої влади в сфері туризму;

Підтримки та оновлення офіційного Інтернет-порталу федерального органу виконавчої влади в сфері туризму;

Організації мережі інформаційних центрів для іноземних і українських туристів в місцях проходження найбільших туристичних потоків при інформаційній підтримці органу виконавчої влади в сфері туризму;

Проведення ознайомлювальних поїздок по курортним місцевостям для іноземних журналістів;

Організації презентацій курортних можливостей України в основних країнах, що є потенційними туристами нашої країни.

Пріоритетні напрямки розвитку санаторно-курортної сфери окреслюються цільовими загальнодержавними програмами, які схвалюються Верховною Радою України (ст. 85 Конституції України) та Постановами, виданими Кабінетом Міністрів та Указів Президента. Основні засади регулювання санаторно- 
курортною сферою закріплені в Конституції України [1].

Основні напрями санаторно-курортної сфери залежать від реалій соціальноекономічного життя країни, а також вирішення проблем.

Дослідження сучасного стану санаторно-курортного розвитку в Україні дозволяє віднести до основних завдань:

a) забезпечення належного рівня фінансування;

б) створення правової бази у галузі, яка б відповідала потребам сучасного світу;

в) охорона природного надбання;

г) підвищення ролі й престижності професії працівника санаторнокурортних закладів [5].

В українських реаліях рекомендується використовувати елементи існуючих систем управління, 3 «американської» - податкові пільги для приватних осіб і корпорацій, податкові пільги для некомерційних організацій, акцій, 3 «британської» - збільшити витрати на курортні зони в держбюджети, 3 «французької» - контроль державних структур у процесі виділення та розподілу коштів, за допомоги місцевих органів влади [2].

Вибір стратегічних механізмів керівництва санаторно-курортних комплексів через аналіз впливу на економічні та соціальні результати зовнішнього та внутрішнього середовища повинні грунтуватися на принципі конкретизації об'єкту та встановлення механізму впливу сукупних умов впливу на результати його функціонування в довгостроковій перспективі.

Головна мета такого принципу полягає в точному врахуванні галузевих властивостей санаторно-курортних комплексів, змісту та складу вирішених соціально-економічних завдань, що дозволяе об'єктивно встановити взаємозв'язок між соціально-економічними результатами іiі діяльності та характеристиками кожного індивідуального елементу середовищ суб’єкта господарювання.

Вплив державних органів на предмет управління проявляється через використання податкових пільг, які $\epsilon$ передбачені державною податковою системою, державного фінансування, через бюджетну систему та інші законодавчо визначені форми, а також використання можливостей інституту державної власності.

Основною такого впливу є визнання законодавчої і нормотворчої діяльності, під час якої воно знаходить практичне застосування в державній політиці, тим самим створюючи тісний зв'язок між цим елементом середовища безпосереднього впливу та політичним середовищем, як складовою чинника непрямого впливу.

Розглядаючи об'єктивні характеристики завдань санаторно-курортних комплексів, які, як правило, мають в основному соціальний характер, та специфіку діяльності закладів, що мають значно некомерційну породу, варто відмітити, що в переважній більшості причин діяльність державних органів має 
вирішальний вплив на результати їх теперішньої діяльності i, перш за все, цілі цієї роботи, в довгостроковій перспективі.

Стан справ засвідчує, насамперед, той факт, що домінуючою формою власності у переважній більшості санаторно-курортних комплексах виступає державна форма власності, а основною правовою формою організацій виступає об’єднане підприємство, тому, можна сказати, що органи виконавчої влади на різних рівнях отримують право безпосередньої участі в керівництві такими об'єктами [3, с. 251].

Чинником, який значно ускладнює ефективне проведення державної санаторно-курортної політики $є$ недосконалість законодавчих актів України. Низькою якістю характеризуються i норми загального та спеціального законодавства, за допомогою яких здійснюється регулювання відносин у сфері

рекреації і туризму.

Соціальна функція санаторно-курортних комплексів в Україні ігнорується i виконується тільки в рамках державних зобов'язань перед певними контингентами населення (військовослужбовці, співробітники МВС, державні службовці, інваліди та постраждалі від аварії на ЧАЕС, хворі деякими захворюваннями та ін.). В рамках такого підходу санаторно-курортна допомога не включена в обсяг гарантованої державою медичної допомоги, а перебування в санаторії не є страховим випадком i, отже, не підлягає фінансуванню по лінії медичного страхування. Одже, недостатньо використовуються можливості законодавчого регулювання і податкового стимулювання курортної діяльності.

Сьогодні санаторно-курортна сфера в Україні загалом, а також в ІваноФранківській області вимагає не тільки збільшення бюджетного фінансування, а ще й суттєве покращення ефективності процесів через впровадження методологій стратегічного управління, що тягне за собою постійну зміну підходів до керівництва економічними та соціальними процесами, а також значні зміни в організації діяльності суб’єктів господарювання та галузі в цілому.

Реалізація державної санаторно-курортної політики на регіональному рівні це, з одного боку, істотна складова стратегії туристичного розвитку України, яка реалізується відповідно до загальних завдань державної політики; з іншого боку, ця політика виступає як самостійна сфера проектної діяльності, що має на меті всебічну підтримку та популяризацію санаторно-курортну індивідуальність кожного регіону, створення умов для розвитку туристичного життя даної територіальної громади.

Регіональну політику потрібно розробляти як складову державної політики, яка поєднує економічні, організаційно-правові заходи, що здійснюються державними органами влади як складову розвитку регіонів на основі підтримки природнього ресурсу, людського, виробничого та при врахуванні особливостей кожної регіональної одиниці у відповідності до державних інтересів. При реалізації регіональної політики держава впливає на стратегію та процеси в регіонах. 


\section{Висновки:}

Регіональний санаторно-курортний проект Івано-Франківської області $€$ принципово важливою формою самовираження та самореалізації. Нові соціальноекономічні реалії та суперечливий характер реформ відновили проектну діяльність на регіональному рівні як засіб покращення туристичної реальності.

Використання проектного потенціалу для санаторно-курортної сфери на регіональному рівні дозволяє:

- розвивати та використовувати механізми його саморозвитку;

- моделювати та прогнозувати пріоритетні напрями та види курортної діяльності;

- створити сприятливе санаторно-курортне середовище, необхідне для людського відновлення.

Саме в об'єднаній територіальній громаді, регіоні народжується стратегія розвитку санаторно-курортній сфері, яка враховує специфічні особливості самих територій, їх історичні та культурні традиції, інтереси та запити різних груп місцевого населення.

\section{Лimepamypa:}

1. Конституція України від 28 черв. 1996 p. № 254к/96-BP. URL: https://zakon.rada.gov.ua/laws/show/254к/96-вр (дата звернення: 12.04.2020).

2. Авер'янов В.Б., Пухтецька А.А. Удосконалення організації та діяльності системи органів виконавчої влади 3 урахуванням європейських принципів і стандартів. Часопис Київського університету права. 2010. №4. С. 110-117.

3. Кіндзерський С.А. Державне управління в гуманітарній сфері регіону України: стан та тенденції розвитку : автореф. дис. ... канд. наук з держ. упр. : 25.00.02 / Нац. акад. держ. упр. при Президентові України. Київ, 2006. 20 с.

4. Гриценко О.А., Солодовник В.В. Шляхи удосконалення фінансування культури в Україні: аналіт. записка. URL: http://www.culturalstudies.in.ua/zv_2004_1.php (дата звернення: 12.04.2020).

5. Олешко А.А. Концептуальні засади антикризового регулювання національної економіки. Економіка та держава. 2012. №9. С. 4-7.

\section{References:}

1. The Constitution of Ukraine from June 28, 1996 № 254k / 96-BP. base. garant. ua. Retrieved from https://zakon.rada.gov.ua/laws/show/254k/96-vr (access date: 12.04.2020).

2. Averyanov, V.B., Pukhtetska, A.A. (2010) Udoskonalennia organizatsiyi ta diyialnosti systemy orhaniv vykonavchoyi vlady $\mathrm{z}$ urachuvaniam yevropeyskykh prykladiv i standartiv [Improving the organization and operation of the system of executive bodies, taking into account European principles and standards]. Kiev [in Ukrainian].

3. Kindzersky, S.A. (2006) Derzhavne upravlinia v humanitarniy sferi rehionu Ukrainy: stan ta tendenciyi rozvytku [Public administration in the humanitarian sphere of the region of Ukraine: state and development trends]: Extended abstract of doctors thesis. Kiev [in Ukrainian].

4. Gritsenko, A.A., \& Solodovnik, V.V. (2020) Shliakhy udoskonalenya finansuvanya v Ukraini [Ways to improve the financing of culture in Ukraine]: base. garant. ua. URL: http://www.culturalstudies.in.ua/zv_2004_1.php

5. Oleshko, A.A. (2012) Kontseptualni zasady antykryzovogo reguliuvania natsionalnoyi ekonomiky [Conceptual bases of anti-crisis regulation of the national economy]. Kiev [in Ukrainian]. 